\title{
Emergent Stateness: Critical Urban Geopolitics in Slavutych
}

\author{
Nathaniel Ray Pickett \\ University of Kansas
}

\begin{abstract}
The city of Slavutych was built specifically to house the workers who would continue to work post-disaster at the Chornobyl Nuclear Power Plant (ChNPP) and their families. It was the pinnacle of Soviet planned cities, the culmination of decades of lessons learned from similar projects, and the architectural embodiment of Soviet multinationalism. However, in spite of all the excitement the new city elicited, within just a few years the now-independent Ukrainian government, under pressure from international organizations like the International Atomic Energy Association and the United Nations, established a hard expiration date for the shutdown of all ChNPP reactors, which in turn would mean economic devastation for Slavutych and render its existence wholly unnecessary. Rather than wait for the inevitable, city leaders and residents leveraged global and national interest in the Chornobyl disaster and its aftermath, drawing investments from multinational corporations, international organizations, and states to keep the city alive. Their scattergun approach to economic diversification and pre-emptive urban revitalization paid off, as Slavutych thrived even as the rest of Ukraine suffered major economic and demographic crises. This paper examines how Slavutych citizens were able to forge, and then to act upon, geopolitical relationships to mitigate the lingering social, political, and economic effects of the Chornobyl disaster in the city. ${ }^{1}$
\end{abstract}

Keywords: critical geopolitics, Ukraine, Chornobyl, urban studies.

\section{INTRODUCTION}

$\mathbf{T}$

The 1986 Chornobyl Nuclear Power Plant (ChNPP) disaster was a technogenic event with massive political, social, ecological, and biological repercussions that resulted in a wide range of state-scale policies and national-scale social transformations and adaptations in Ukraine (Baranovs'ka; Yekelchyk; Imanaka; Shevchenko). This paper reports a micro-scale investigation into co-productive relations among technoscientific knowledge, non-human actors, ${ }^{2}$ people, and institutions by

\footnotetext{
1 This research was made possible by a 2015-16 Fulbright fellowship.

2 Some of the non-human actors considered here are radioactive particles, procedures and protocols (like in disaster management, information management, nuclear plant safety, etc.), borders, architecture, and ideology.
} 
exploring the historical development of Slavutych, the city built as a replacement for the abandoned Prypiat to house Chornobyl Nuclear Power Plant (ChNPP) workers and their families. Local policies and practices are a constitutive part of the wide constellation of human political activity, with direct, but often overlooked, ties to institutions, organizations, individuals, and objects in other places and at other scales. Slavutych used local expertise to forge connections with global, national, and transnational actors to save itself and to drive geopolitical discourse on nuclear energy and on Ukraine's geopolitical relationships.

Urban geopolitics are usually framed in terms of the effects that cities have on grand geopolitical narratives, especially those concerned with conflict and war. While there is some engagement with critical geopolitics scholarship-for example, in investigating geopolitical relationships that go beyond interstate interactions - the developing literature on urban geopolitics largely leaves out some of the more recent developments in the field, such as the focus on material and localized expertise. ${ }^{3}$ This author makes an effort to bridge that gap by focusing on how Slavutych, a small city in northern Ukraine, has been able to leverage its technoscientific expertise and lived experience to work directly with international organizations, other states, and multinational corporations to serve the needs of this city and to influence geopolitical narratives on national and international scales.

Slavutych's localized technoscientific expertise emerged as a result of the city's development and its direct links to the Chornobyl disaster. After the evacuation of the Chornobyl Zone, Soviet officials deemed it necessary to construct a new city to serve the ChNPP workers and their families, as three of the four reactors were still operational. By design, this city has become a centre of knowledge and expertise about Chornobyl-originating radiation, radioactive contamination and exposure, and the realities of living with an ineradicable legacy of a major technogenic disaster.

This paper frames its analysis of Slavutych as a state-like entity and as an assemblage; it is an effect of a complex web of the relations among events, actors, material, and processes that "acts" like a state in its interactions with other entities. The second part of the paper is a short history of Slavutych, depicting the particulars of its construction and development, and the challenges it has faced over three distinct time periods: its construction in 1988 to the Memorandum of Agreement in 1995 that dictated the early decommissioning of the ChNPP, the five-year period (1995-2000) of preparing for the early decommissioning, and from 2000 to the present. The

\footnotetext{
3 Such as centring the material (or non-human actors) in social processes (for example, Barry and Dittmer, Diplomatic Material) and recasting geopolitical discourse as the result of interactions of local experts instead of grand narratives (for example, Kuus).
} 
third part of the paper explores the roles of city officials in forging connections with different entities and organizations across a number of scales (local, inter-urban, national, regional), external interventions in Slavutych, and the effects of grassroots activities and activism within the city. The final section investigates whether Slavutych's experiences can constitute a suitable model for other post-disaster cities.

I conducted research for this paper primarily via multiple visits to Slavutych, by interviews with city leaders and residents, and through archival research in the Slavutych city archives, the Kyivska oblast archives, and the Ukrainian national archives.

\section{CRitical Geopolitics, AsSEMblaGes, And the StATE-As-EFFECT}

The Chornobyl disaster was global in its effects, and in its handling-by media, by governments, by scientists, by organizations, by affected populations. The disaster was rife with explicit geopolitical considerations, particularly in two major arenas: the material and the discursive. In the material arena, the Chornobyl disaster was an international incident with international material effects. The radioactive dust cloud resulting from the explosions was not confined to the borders of Ukraine, or even to the borders of the Soviet Union. In fact, it was Swedish weather recording instruments that first detected the cloud, alerting Western Europe to its presence. Cold War politics and the magnitude of the disaster prevented American and European researchers from pinpointing the source of the plume, though it was presumed to have come from somewhere in the USSR (Petryna 36-38). After the Soviet Union revealed that the source of the plume was the Chornobyl nuclear plant, a number of international organizations - the International Atomic Energy Association (IAEA), the Atmospheric Release Advisory Capability (ARAC) at Lawrence Livermore National Laboratory in California, the World Health Organization (WHO), and the UN Scientific Committee on the Effects of Atomic Radiation (UN-SCEAR)-got involved. These and other organizations provided expertise, instrumentation, and financing to measure and treat the effects of the radiation to augment the resources and capabilities assembled by the Soviet Union. Within a few short years of the initial disaster response, many international charity organizations formed to serve those affected by Chornobyl radiation, the Soviet Union dissolved, and Ukraine turned to the European Union (EU) for aid for Chornobyl and for membership in the EU. Recently, a number of transnational or foreign (i.e., non-Ukrainian) entities have become involved in designing and building a new safe confinement shelter over the reactor, replacing the hastily constructed initial sarcophagus. 
Geopolitical narratives about the Chornobyl disaster, its political ramifications, the effects of radiation on bodies and ecologies, and threats to humanity from the global nuclear industry amassed in the aftermath of the Chornobyl disaster. Tracing the contours of the geopolitical discourse related to the Chornobyl disaster is the purview of critical geopolitics, which de-centres nation-states and the state system and focuses instead on the discourse itself, its authors, its schisms and changes, and its effects. The discursive narratives within and about Ukraine and Chornobyl are politically motivated narratives that generally concern power (Ó Tuathail, Critical Geopolitics). Analyzing the relationships among policy-making, technoscientific knowledge production, and geopolitical narratives advances the project of critical geopolitics, disrupting the state-centric, political realist idea of geopolitics, and lends itself to conceptualizing the organizations, people, material, narratives, and relations among them as parts of assemblages.

Critical geopolitics "interrogates how and why we have come to think of the world (or parts of it) in a certain way" by taking seriously the roles, influences, and actions of cultural authorities, the media, academics, think tanks, policymakers, and people (Dittmer, Popular Culture 11). Central to critical geopolitics is a decentring of the nation-state as the only or primary unity of analysis, and recognizing that just as power flows multidirectionally across social relations (see Foucault; Ó Tuathail, Critical Geopolitics; Ó Tuathail et al., The Geopolitics Reader; Atkinson; Hepple), political narratives and actions are produced and undertaken in all parts of society. For all this groundwork and continual development of critical geopolitics, there remain gaps, such as how cities affect and are affected by geopolitical narratives. What work has been done in this area tends to focus on the development and role of world cities, particularly in globalization discourse (for example Graham). One aspect of this paper is to investigate how a small, new city and its residents have been able to enact geopolitical relationships and drive geopolitical narratives.

The small but growing literature on urban geopolitics is primarily concerned with conflict in urban spaces (see Brenner "Beyond StateCentrism?" and "The Urban Question"; Cowen and Smith; Jonas; Rokem and Boano). Rokem and others recently sought to expand the scope of urban geopolitics beyond a focus on conflict ("Interventions" 2). They outline four interventions into urban geopolitics: ordinary urban geopolitics of segregation and mobility, domestic urban geopolitics, urban geopolitics of refuge, and geopolitics of urban verticality. These studies look at how geopolitics is played out in urban spaces. My research on critical urban geopolitics begins outside of urban studies and urban geography scholarship. Instead, I am interested in how urban spaces incorporate themselves into geopolitical narratives; that is, I consider the city as an 
assemblage. By taking an assemblage theory approach to political theories of the state and recontextualizing the state not as a subject-object but rather as an emergent affective assemblage, the various tools available for state analysis become available for non-state polities, including cities.

Dittmer in Diplomatic Material employs a "microscaled analysis of state foreign-policy apparatuses" to trace the constellation of actors and processes that make up the notion of the state, exposing the state as a becoming-being rather than as a discrete subject-object of analysis (4). For example, in tracing the development of the British Foreign Office in the nineteenth century, Dittmer foregrounds the bureaucratic-material context of foreign policy creation by focusing on the circulation of paper (such as dispatches and archives) and the architectural debates over building a new Foreign Office in Whitehall in 1858. This micro-scaled approach "deemphasizes anthropocentric agency and instead emphasizes the morethan-human nature of diplomatic practices and the affective forces that shape the spaces in which policy making occurs" (Dittmer, Diplomatic Material 17). As mentioned above, the trend within critical geopolitics has generally been to move away from the state-viewing it as both a territorial trap for geopolitical analysis and a tool for advancing imperial/neo-liberal agendas-in favour of studying state effects at different scales. Recently however, there has been a growing literature rehabilitating the state within political geography by taking inspiration from the humanities (see Painter) and science and technology studies (for example, Anderson and McFarlane; Barry; Kuus; Müller; O'Lear). Dittmer's intervention-a micro-scaled analysis via assemblage theory-uses the mundane, prosaic effects and materials of various performances of stateness 4 to demonstrate the translocal nature of the state. By looking at state theory through practices of everyday life, Dittmer sees the state emerging "from the enmeshing and interaction of various local events and phenomena" (Diplomatic Material 5). This leads to an understanding that while "the state appears to be a transcendental subject that orders the political world ... in reality it is the effect of that political world" (Dittmer, Diplomatic Material 6). Treating states as effects invites the opportunity to explore polities (like a city, for example) that emerge in similar ways at other scales and undertake similar endeavours.

The essence of the state-its stateness-therefore refers to a set of effects, practices, material, and phenomena through which a polity can structure social (or socio-material) relations rather than relying on the

\footnotetext{
${ }^{4}$ Dittmer offers one example of performances of stateness when he looks at how the circulation of papers, in the forms of reports, communiques, and dispatches, shaped the development of the British Foreign Office in the nineteenth century (Diplomatic Material 25-48).
} 
tautology of stateness defined as the essential characteristics of a state. In other words, a state is an assemblage of social-material-political effects with the institutional means of inserting itself-symbolically, materially, ideologically - into, and thereby structuring, any number of social relations in its relational network. Assemblage theory emerged out of the philosophy of Deleuze and Guattari (see also DeLanda) and has taken root in human geography, as well as in other disciplines, over the past decade. Assemblage theory sets itself against totalities, instead viewing social formations as relations among temporary groupings of component parts, such as humans, things, institutions, cities, and so on, that can be arranged and re-arranged. The relations among these component parts are relations of exteriority, which implies both a kind of autonomy of the component parts and that "the properties of the component parts can never explain the relations which constitute a whole" (DeLanda A New Philosophy 11). These heterogenous arrangements are also productive in that the effects of the relations among an assemblage's component parts are also causal; an assemblage is an arrangement of various components with agency. That assemblages produce effects is key to the metaphor's usefulness and is what moves "assemblage" beyond being a descriptor. To use a relevant example, a city is more than just its buildings, roads, parks, monuments, and symbols; it is more than its people and their political, social, cultural, and economic interactions. Beyond simply being more than a sum of its parts however, the combining and rearranging of an assemblage's constituent parts constantly produces new effects as those constituent parts relate in new ways in their new combinations. To continue the previous example of the city, while the buildings and roads may remain the same, they may take on new meanings as businesses close and open, populations change, and city ordinances get revise. Examining states as effects in the frameworks of prosaics and assemblage theory highlights the "openness, porosity, heterogeneity, fallibility, unevenness, and creativity of state practices" on the one hand, and an erosion of the state-nonstate binary on the other: "Instead of ruling certain states 'in' and other polities 'out,' we can begin to think of all polities as exhibiting certain qualities associated with stateness, while lacking others" (Painter 770; Dittmer, Diplomatic Material 7). The metaphor of "stateness" used in this paper points to the idea of a state as a complex relational effect that is not confined to one particular scale.

With a definition of the state thus divorced from the scalar imagination thereof, any polity exhibiting stateness can be analyzed as a state: in its prosaics, in its translocalities, in its governmentalities, in its structuring effects on the social and material relations that constitute it, in its collective will, in its affective orientations, in its shifting claims and control over spaces, in its interactions with other stately polities. This paper analyzes Slavutych's stateness, especially in its geopolitical actions and connections. 
It focuses on the production of Slavutych's stateness through its constitutive local events and phenomena, discussed in the next section, and how the Slavutych state assemblage (or actors within it) activated its constitutive elements in its interactions with other states to achieve results. The study of how Slavutych leveraged its local technoscientific expertise in a number of geopolitical configurations, bridges the conceptual gap between the disavowal of the state in political geography at large and the looming presence of states, state technologies, and manifestations of state-like powers in political arenas at any scale. This approach expands the vistas of political geography for novel research and can serve as a basis for a critical urban geopolitics within the field of geography.

\section{A History OF SLAVUTYCH}

The scope, severity, and material reality of the 1986 accident at the Chornobyl Nuclear Power Plant necessitated a large-scale evacuation of hundreds of thousands of people from the most highly-contaminated areas in Polissia, a region in north-central Ukraine and southern Belarus. In addition to hundreds of villages and small towns, the city of Prypiat, the nuclear monotown built to house and service the workers at the ChNPP, had to be abandoned even as the three other working reactors at the plant continued operation. As such, authorities bussed in essential plant personnel along with firefighters, police, military, and volunteers taking part in the liquidation efforts, while recognizing that such an arrangement was not suitable in the long term. By 2 October 1986, Soviet and Ukrainian officials had decided on the construction of a replacement city for Prypiat, 50 kilometres to the east, on the other side of the Dnipro River. Development and construction of the city were overseen and financed by a bevy of Soviet ministries with the participation of eight Soviet republics; it was indeed an all-Union project. In the years since its opening in 1988, however, Slavutych has weathered major transformative events that have required a fundamental shift in the city's identity and in the identity of its residents. The argument presented here is that Slavutych has heretofore been able to successfully reinvent itself, simultaneously diversifying its economy away from dependency on the ChNPP plant and embracing the legacy of the Chornobyl disaster, not as a tragedy but as an opportunity. These accomplishments were due largely to the ability of Slavutych citizens to leverage local experience and expertise across networks of actors, including international organizations, state governments, multinational corporations, and sympathetic individuals; in effect, Slavutych used geopolitics to save itself. 
Documentary and archival evidence indicate that Slavutych was originally designed to be an international city. As a nuclear monotown, Slavutych reflected both the Soviet Union's global position as a nuclear leader and originator and major proponent of the "Peaceful Atom" ideology and the centralized but all-Union nature of the Soviet nuclear program. The USSR had built nuclear power plants in Russia, Ukraine, Armenia, and Lithuania; it used sites in Siberia, Kyrgyzstan, Uzbekistan, and Kazakhstan (among others) for mining, fuel enrichment, and spent fuel storage; and it recruited nuclear engineers from member republics to be trained in Moscow. The greater aspects of Slavutych's internationality, however, were its planning and material construction. Two Soviet ministries-the Ministry of Energy and the Ministry of Atomic Energy, both reporting to the Central Committee of the Communist Party of the USSR and to the Ukrainian SSR's government-had general oversight for the construction of the city, but employed builders from Russian, Ukrainian, Estonian, Latvian, Lithuanian, Georgian, Armenian, and Azerbaijani SSRs (Zasedaniia). Each nationality was tasked with constructing its own quarter within the city in a manner that reflected aspects of its national heritage, in the interest of exhibiting the multi-ethnicity of the Soviet Union. The result of this construction plan is a vibrant environment with visible differentiation in the city's quarters: from the single-family homes of the Leningrad quarter to the Armenian frescoes on the walls of the Yerevan quarter to the girih-style windows in the Baku quarter, each neighbourhood looks and feels distinct (see Gubkina for detailed pictures and descriptions of each quarter). Furthermore, the direct rail line that transports workers from Slavutych to the ChNPP plant cuts through the southernmost part of Belarus.

The city's design also served as a showcase of Soviet urban planning, functioning as the pinnacle of the field, as Slavutych would be the last city built in the Soviet Union, and is to this day the youngest city in Europe. The city is small, with a planned population of 25 thousand, and an emphasis on physical activity, education, and public participation is evident in the layout of the city. City planners prioritized green space (official documents show that only trees necessary to be cleared for constructing roads and buildings should be removed), resulting in, for example, a grove of old-growth trees in Slavutych's central park (Zasedaniia). Slavutych's design demonstrated a conspicuous effort to territorialize a constellation of Soviet political agendas (socialist utopia, the peaceful atom, brotherhood of nations) in an era where many fundamental givens of the Soviet system were being challenged by Gorbachev's glasnost' and perestroika initiatives. The license afforded by Gorbachev's reforms, however, meant that Slavutych's planners could, in the context of new urban planning ideas such as the "eco-city" (see Register; Gubkina), call back to, in Mariusz Czepczyński's words, the "main fundaments of socialist architecture": "the will to change society by or 
though architecture, design, and cultural landscape" (63). The design for Slavutych integrated the past in its conscious resurrecting of the oldest ideas in Soviet urban planning and the future in its synthesis of high technology (nuclear energy) and intimation of the Socialist Man. Blair Ruble insightfully noted:

An examination of urban form and the processes by which it has come into being reveal a great deal about its creators. The building of a city involves every aspect of human existence. It blends the economic with the political, and the social with the cultural, into material expression of otherwise abstract and remote 'tendencies' and 'forces.' (205)

The design and construction of Slavutych did just that, giving the glasnost'-era Soviet ideology form. Within a year and a half of the city's completion, however, the political and economic institutions undergirding that ideology broke down in the dissolution of the USSR.

After the collapse of the Soviet Union, Slavutych could no longer rely on the forms of assistance, dependence, and integration to which it was accustomed. With Ukrainian independence came an immediate stoppage of material, scientific, organizational, and financial support from Moscow to the ChNPP, which was the lifeblood of Slavutych's economy as an atomgrad, a nuclear monotown-it was a fundamental rupture of the nested hierarchy upon which the new city relied. For Slavutych, however, Ukrainian independence brought no immediate material changes: the plant was still running. Rather than national political changes, the major threats to the continued operation of the ChNPP in this period came from technoscientific issues from within the plant: "expert" technical opinion, scientific bodies, and the state security service. As problems continued to mount at the plant, including a fire on 11 October 1991 caused by an electrical short circuit in turbine number 4 (see M. Holushko to V. Iavorivs'kyi), calls for the early decommissioning of the plant, an option that had been on the table in the immediate aftermath of the 1986 accident, grew louder. Such a decision could not be taken lightly: an early decommissioning of the ChNPP would mean that Kyiv's energy needs would have to be met by other means, and the city of Slavutych would face mass unemployment, economic devastation, and an uncertain future for all its residents.

This anxiety about the future was baked into the foundation of Slavutych. City leaders from the beginning endeavoured to establish an identity for Slavutych and its residents that would be resilient enough to weather a catastrophe, such as early decommissioning of the ChNPP. In the initial period of the city's history, this largely took the form of fostering Ukrainian identity, even before independence. Ukrainian-language instruction was adopted in Slavutych's schools, education received increased investment, city administrative functions embraced transparency 
and openness (Udovychenko, personal interview). These social overtones contrasted with the intentional all-Union plan of the city; while the material processes of its construction were firmly embedded in the politics of Soviet unity, its social processes-actual, everyday life in the city-eschewed those politics for more explicitly nationalist ones in a formulation that Wilfried Jilge cheekily called "Soviet in form, but national in content" (Kliems and Dmitrieva 148). As the city's economy was based on the operation of the ChNPP, it was in the city's interest that the plant remain safely operational for as long as possible.

In 1995, after a series of meetings with the European Commission and the G7 countries (Japan, the United States, Germany, Italy, the United Kingdom, France, and Canada), Ukrainian President Leonid Kuchma attested that Ukraine would close the ChNPP by 2000. The resulting Memorandum of Understanding between the G7 and Ukraine that same year outlined a timeline for plant closure, programs for mitigating social and economic issues resulting from plant decommissioning, and an allotment of over $\$ 2.3$ billion in international funding to cover power sector restructuring, energy investment, nuclear safety reform, plant decommissioning, and social impact planning (Parliamentary Assembly appx. IV). This large sum-almost 5\% of Ukraine's 1995 GDP-along with the language at the beginning of the document acknowledging that the decommissioning of the plant would be costly and would possibly result in major economic and social consequences for Ukraine, demonstrated the importance of the plant's closure to the international community. After a drawn-out negotiation process, in which Ukraine's leaders had some leverage over the G7 in financing the early decommissioning because of international pressure to close the plant, Kuchma finally announced in June 2000 that Chornobyl would close on 15 December of that year (The Associated Press).

In this material and (geo)political context, Slavutych faced essentially a hard deadline on a transition out of being a monotown and into having a diverse economic foundation for the city. In a city of about 26 thousand people, where $35 \%$ of the population was younger than 16 , another third (almost the entire male workforce) were employed at the ChNPP, and 22 thousand residents received Chornobyl benefits, losing the plant would have a devastating effect (Slavutyts'ka mis'ka rada, Plan dii 80-81). At the time of its shutdown, the ChNPP employed 9000 people; ongoing decommissioning efforts required less than 2400 persons (Chernobyl NPP). By the mid-1990s, many small and single-industry towns across the former Soviet Union had faced similar issues, and as a result many of these places had experienced rapid depopulation (French 127-28). To avert an economic and demographic catastrophe, Slavutych city leaders, led by long-time mayor Volodymyr Udovychenko (city head 1990-2015), proposed and implemented numerous actions designed to soften the blow of suddenly 
having six thousand unemployed highly-skilled workers. These actions involved the expertise of locals gained from dealing with the aftermath of the Chornobyl disaster, and from 1995, Slavutych began in earnest to leverage the expertise of its residents in forging connections with state and international institutions. It was in these efforts that Slavutych's stateness began to emerge. Faced with a grim future if nothing changed, city leaders and residents envisioned a future version of the city: democratically functioning with engaged residents and a productive, diversified economy. The ensuing arranging and rearranging of Slavutych's constituent parts, which also included attracting new constituent parts from other assemblages, such as special state funding or foreign investment, was a conscious effort to re-shape Slavutych.

In 1997, the Slavutych City Council published its first Action Plan with support from USAID and the European Commission's Technical Assistance to the Commonwealth of Independent States program. The Action Plan proposed four major recommendations for the diversification of Slavutych's economy: establish an organizational foundation for socio-economic development, create a financial base for the city, create a Slavutych entrepreneurial development program, and develop human resources services within the city (Slavutyts'ka mis'ka rada, Plan dii 70-71). Two central features of the specific actions proposed in these general recommendations were an expanded role of local government, especially in business and finance, and intentional international co-operation initiatives:

- $\quad$ Build new business and work places in the city;

- Form an agency for business development, the Association of Goods and Services Suppliers to MOU Projects;

- Work more closely with contacts in the Chernihiv oblast;

- Ensure maximum participation of ChNPP workers in city initiatives;

- $\quad$ Create a new tax plan;

- $\quad$ Become more energy-efficient;

- Establish a mechanism to guarantee investments for economic diversification projects;

- Establish a mechanism to attract foreign investment and international co-operation;

- $\quad$ Create a city development fund;

- Transfer assets from the ChNPP to the city;

- Establish an industrial park, a technopark, and an incubator for local small and medium businesses;

- $\quad$ Provide counselling and retraining services for ChNPP employees;

- Expand the health and medical facilities in the city. 
In addition to the measures proposed in the Action Plan, the Slavutych City Council relocated the Chornobyl Centre for Nuclear Safety, Radioactive Waste, and Radioecology from Kyiv to Slavutych and convinced the national government to establish a Special Economic Zone in Slavutych to provide tax incentives for business growth in the city. This scattershot approach to encouraging economic diversification has yielded limited results in terms of spurring economic growth, though taken collectively, these activities certainly softened the blow of the plant's closure. After the plant closed on 15 December 2000, approximately 5800 Slavutych ChNPP employees lost their jobs, and many moved out of the city. However, largely because of the proactive efforts of city leadership and residents, the situation in the city after the plant's closing was not so dire: unemployment, in 2000 as high as $6.05 \%$, reached less than $2 \%$ by 2007 ; average income for Slavutychany has increased every year since 2000 at a rate outpacing the Kyiv oblast as a whole; and as a cost-saving initiative, energy consumption and expenditure in the city has substantially decreased since 2000 (Slavutyts'ka mis'ka rada. Prohrama 11). ${ }^{5}$

Slavutychany were enticed to not give up on the city after the plant's closing in two substantial ways. (1) The mayor, Udovychenko, had successfully heightened the interconnectedness of the city and its residents; that is, he reconceptualized Slavutych as a state-like entity and fostered local identity. The Chornobyl disaster was already a huge element of daily life for everyone in Slavutych-it was, after all, the reason the city existed at all. Reconceptualizing the Chornobyl disaster as a possible source to be drawn upon for urban regeneration rather than just as a tragedy, made Slavutych's urban regeneration personal. (2) The mayor had convinced Slavutychany to trust him. He gained that trust by developing city institutions, like those listed above, involving as many people as possible in various committees and initiatives, and by personally forging connections with other cities, governments, organizations, and businesses, such as sending a Ukraine delegate to the Congress of Local and Regional Authorities of the Council of Europe from 1994 to 2015.

These two factors reinforced each other, so while it is fair to say, as does the current mayor Iurii Fomichev, that, "like him or not, without Volodymyr Petrovych [Udovychenko] there would be no Slavutych today," the corollary is true that without broad public participation in city administrative policies and practices, there would be no Slavutych today (Fomichev). From this perspective, seeing Slavutych as an assemblage is straightforward. The

\footnotetext{
${ }^{5}$ As indicated by the citation, these numbers come from Slavutych City Council publications. Attempts to reach the State Statistics Service of Ukraine from outside the country for more detailed employment statistics, including changes in employment at the ChNPP, have been unsuccessful.
} 
residents, leaders, physical space, material resources, lived experience, and scientific expertise that make up the city are continually reconfiguring the city. This constant reconfiguring and reterritorialization of Slavutych expresses the city's desire to be more, to "produce new things, new life, and new ways of being in the world" (Dittmer, Diplomatic Material 10). This productive potential of Slavutych is best demonstrated in its forging of connections with other state-like entities and international organizations.

\section{CONNECTIONS AND DisCONNECTIONS}

Much of Slavutych's success in transitioning from a Soviet monotown into a thriving twenty-first-century city can be attributed to the productions and manifestations of its stateness. The local and global processes that have shaped the development of Slavutych are tightly interwoven: city leaders and residents have developed these ties in many ways, all of which involve deploying local experience, knowledge, and expertise along local-to-global networks. Slavutych's localism, both as a critical response to processes of globalization and as a deliberate emphasis on diffuse leadership, sustainability, local identity, and community self-reliance, is rooted in interdependence. The existence of the city itself is a result of global, national, scientific, and intergovernmental processes; rather than spurn its global provenance, Slavutych has embraced it and endeavoured to use it to the city's benefit.

One example of Slavutych's collaboration with international organizations is Resolution 215, issued by the Congress of Local and Regional Authorities (CLRA) of the Council of Europe. In it, the CLRA urges "local and regional authorities of the member states of the Council of Europe to put into practice in their actions and policies the principles presented in the Slavutych Appeal," which outlines five principles intended as guidelines for local governance in areas where nuclear safety is a concern (Congress of Local and Regional Authorities). The five principles in the Slavutych Appeal are: (1) the nuclear industry must be a government responsibility if any global nuclear safety is to be attained; (2) local governments must take an active, frontline role in protecting communities and the environment from nuclear disasters; (3) as nuclear disasters know no borders, nuclear safety must be realized through cross-border co-operation; (4) the nuclear industry must operate with maximum transparency; (5) the public, locally, nationally, regionally, and globally, must be involved in major decisions regarding nuclear energy (Congress of Local and Regional Authorities 1-2).

The Slavutych Appeal is a result of Udovychenko's, and Slavutych's, experiences with and orientations to the ongoing Chornobyl disaster. Each of these elements also demonstrates expressions of Slavutych's stateness. 
Despite embracing market principles rather wholeheartedly, the nuclear industry should not be privatized but should be regulated by local and regional governments. Local and regional authorities should take the lead in local and regional issues, advocating a more decentralized governance structure. In the event of a disaster, local and/or regional governments should treat each other as equal partners "irrespective of the state to which they belong" (Congress of Local and Regional Authorities 2), explicitly advocating the kind of local-to-global networks Slavutych had been cultivating. Points (4) and (5), on transparency and public involvement, can be seen as direct refutations of Soviet nuclear policies, further political decentralization in elevating the importance of the local, and an expansion of Udovychenko's emphasis on maximal public involvement in governance, which I will explicate below. The five points of the Slavutych Appeal are designed to reconfigure relationships between local governments, states, and international organizations so that interlevel collaboration is fostered to further a common goal, in this case a goal of global nuclear safety. The Slavutych Appeal sees global effects not as "simply the aggregate of various locals" (Dittmer, Diplomatic Material 5), but as emergent products, assemblages, of actions and relations at local and even micro-scales (such as a three-day international conference, "Chernobyl, 20 Years on: Local and Regional Authorities Dealing with Disasters," held in Slavutych on 2-4 March 2006) (Congress of Local and Regional Authorities 1).

The Slavutych Appeal can also be read as a material and discursive encapsulation of Slavutych-style governance as a model. In fact, Udovychenko has often stated that not only is Slavutych unique, it should also be held up as an example to all kinds of different cities, whether they are small, inhabit post-disaster areas, are post-Soviet or European, or any combination of those (personal interview; "Slavutych City"). By the time the CLRA produced Resolution 215 in 2006, the governing principles contained therein had already been in daily practice in Slavutych for almost two decades. In conversation, Udovychenko is proud of how he shaped the functioning of Slavutych, mainly by maximizing public participation in local administrative decisions (Personal interview). The heightened integration of the government initiatives in the lives of Slavutych residents expressed the city's statization. Weekly town hall sessions where residents can voice concerns directly to city administrators, involvement of the Youth Council in every session of the city council, and making summaries and videos of every city council session available on the city's Facebook page, highlight the prosaic interconnectedness of Slavutych and its residents. As Slavutych exercises its stateness and increases its symbolic and institutional presence in the lives of the people who live there, Slavutychany-far from a homogeneous lot-feel a heightened sense of ownership in the direction of the city's development. 
Udovychenko and other civic leaders in Slavutych, including the current mayor Fomichev, a real estate developer whose mayoral campaign was endorsed by Udovychenko, have long touted the city's uniqueness. The impression of Slavutych's uniqueness has also been reinforced in the city's dealings with the Ukrainian central government, with supranational organizations, and in its online branding efforts. The city, its history, and its architecture have become popularized in books, such as Gubkina's Slavutych Architectural Guide; on travel blogs, such as those produced by Megan Starr and Aleksandr Belen'kii; as part of Chornobyl tours (Chernobyl Tour); and in Western news outlets like Wired (Williams) and The Wall Street Journal (Hodge). A central pillar that ties Slavutych's uniqueness to its stateness is Slavutych youth, which has been mobilized in comparison to youth in other cities, regions, and states.

The focus on the youth in Slavutych has been a priority from the beginning. Like Prypiat, Slavutych is inhabited primarily by young professionals working at the ChNPP and their families. I spoke with Ol'ha, who was the first (and for a while the only) ninth-grade student in Slavutych when her family moved into the city in 1988. She told me she "loved growing up here so much, of course I wanted to raise my own children here" (Korchak). ${ }^{6}$ Her oldest child recently graduated from college and has returned to Slavutych to work as a press officer for the ChNPP; he is also currently active in bolstering the city's online presence, including having led a branding campaign to select a logo and slogan for Slavutych, shown below:

Fig. 1. Recently-adopted logo and slogan of Slavutych: "Slavutych: City of New Ideas.” Slavutyts'ka mis'ka rada, http://eslavutich.gov.ua/SitePages/home.aspx

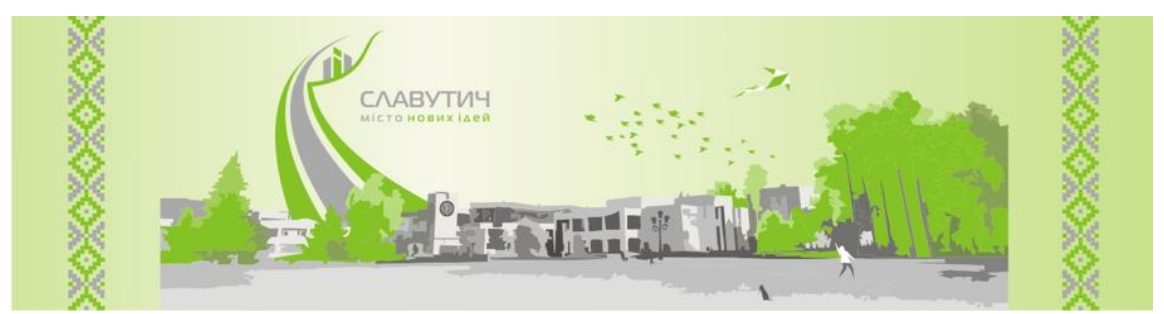

Ol'ha's sentiment that Slavutych is a good place to raise children is reflected in the demographics of the city, especially in contrast to broad population trends in Ukraine.

In 2015, the Slavutych City Council produced an "Investing Passport" to sell the idea of the city. One of the advertised selling points in that brochure

${ }^{6}$ All translations are my own. 
is the median age of thirty-two in a city of twenty-five thousand, where seven thousand of its residents are under eighteen. The city council even lists the rate of natural increase (RNI) per thousand people in the city at four per year (Slavutyts'ka mis'ka rada, "Investytsiinyi pasport" 7)7. This statistic is almost the inverse of the rest of Ukraine: according to the database of the State Statistics Service of Ukraine, the estimated 2016 RNI for the country was 4.3; there has not been a positive RNI for Ukraine since 1990. Following the closure of the ChNPP in December 2000, there was some population outflow from Slavutych: in 2000 there were 25,227 residents and in 2003 the number had dropped to 24,398 . The population remained relatively stable until 2009, and has grown every year since, reaching 24,826 in 2012 and 25,096 in 2017 (Slavutyts'ka mis'ka rada, Prohrama 10; Derzhavna sluzhba statystyky Ukrainy). The city has consciously invested in and promoted the idea of youth abundance in the city, from its commitment to high-quality education to the foundation and incorporation of the Youth Council within the city administrative apparatus. The Youth Council sends delegates to city council meetings and the city cannot decide issues that pertain to young Slavutychany without consultation with and the agreement of the Youth Council.

Most recently, one of the most significant youth-led, grassroots activities both within and for the benefit of Slavutych has been the development of the Festival of Film and Urbanism "86," held on the weekend closest to the anniversary of the Chornobyl explosion. Founded by Nadia Parfan and Illia Gladshtein in 2012, 86 began as a curatorial initiative to highlight and encourage small-town urban culture in Ukraine, and has expanded to encompass an international film festival, a Ukrainian short-film contest called MYSTREETFILMS, an independent documentary film distribution company, the Slavutych Film Commission, and a local art initiative called Made in Slavutych. The annual festival brings in hundreds of international participants and attracts hundreds more festival goers from within Ukraine that lodge and spend money within the city, which in turns attracts vendors from Kyiv and Chernihiv, the two closest major cities. The group's mission is mostly concerned with access to and production of culture in smaller cities and the relationship between culture and urban spaces, but its identity and efforts are very much tied to the legacies of Chornobyl. The choice to base 86 in Slavutych and to grow within and from that space was deliberate: one of 86's defining characteristics is in fact its take on the Chornobyl disaster, consciously choosing to take that event and its aftermath not only as a tragedy, but as an opportunity for renaissance on an urban level with Slavutych, on a national-cultural level, and on a global level, especially in

7 The Slavutych City Council recently updated their "Investing Passport." Reference here is made to the 2015 version. 
dealing with shared issues in post-industrial cities around the world. The film festival has become the primary cultural connector for Slavutych, working parallel to the city's other initiatives of local-to-global co-operation discussed above, yet it is also a distillation of the processes by which Slavutych has endeavoured to reinvent itself. Furthermore, the city's embrace of 86, including official support and hundreds of hours of volunteer support from local residents, serves Slavutych's state-like cultural development interests by forging narratives about its history, identity, and relations.

These initiatives, from the first Action Plan to the 86 Film Festival, are indicative of a mentality within the city that prioritizes the local, promoting a narrative of uniqueness and self-starter independence yet not doing so at the expense of its exterior relations and connections. Udovychenko's current position in the administration of the Kyivska Oblast, of which Slavutych is an administrative exclave, and as an active member of the Congress of Local and Regional Authorities of the Council of Europe provides a direct connection between the city and larger expressions and scales of state power.

\section{Critical Potential}

Distance and relationship are consciously mediated in Slavutych. It is administratively but not geographically a part of the Kyiv oblast. It is forever tied to the ChNPP in its history and in the occupations of its residents, but it is fifty kilometres from Kyiv over a railway that crosses international borders. It is undeniably Ukrainian, but also proud of how it is differentiated from national trends and material realities. In contrast to many cities, especially capital cities, in former-Soviet countries where nationalist narratives are more fully promoted and realized, Slavutych is a rich venue "for the unfolding of many other identities that may complement, undermine, or remain ambivalent to official nationalist narratives and state ideologies" (Diener and Hagen ch. 16). This conscious mediation makes it easier to conceive of Slavutych in assemblage terms: it is a whole, but not a totality; it is a component part of other assemblage-entities-Ukraine, the Chornobyl disaster-yet it demands to be considered on its own and acts according to its own will. While it is not my argument that every assemblage has stately qualities, by investigating Slavutych as an assemblage, its stateness and state-like practices are revealed as emergent social processes that help to (re)produce both Slavutych itself and the other assemblages it constitutes. In treating Slavutych, or any city, organization, or institution from micro- to macro-scale that expresses stately qualities, the methodological tools of political geography and related disciplines for analyzing states and state actions become available. The flatter ontology of 
what is considered a state (or state-like pol/ent-ity) erodes the notion of "The State" as a discrete, more-or-less neatly bounded category of analysis, and further exposes the heterogeneous complexity of the social world and the political relations among participants in it.

The most pressing question for Slavutych, now that it has successfully weathered the transition from monotown to diversified economic base, is whether the city's development can serve as a model for other post-disaster cities. Situating Slavutych in any comparative analysis, however, will require future research; obtaining the information needed to write this paper took multiple site visits, physical access to the city archives, and several interviews, many of which would have been impossible to conduct without being there in person. While some aspects of Slavutych are unique-building new cities in the aftermath of major disasters is not a trend-there are other cities that must confront lingering political and social effects of technogenic disasters. Taking an assemblage approach emphasizes the materials and actors working to continually produce Slavutych, rather than treating the city as a static, monolithic object. A focus on the city-as-subject must be shifted to a conceptualization of the city as an emergent process, affected by the relations and interactions of its component parts. Additionally, by taking seriously the prosaics of the city-the everyday practices that do the messy work of reterritorializing the city-the city is revealed to be produced via multiple competing, or at least contemporaneous, contingencies; no city, or any assemblage for that matter, is, it is always becoming. The flat ontology of assemblage is also useful for comparisons-I have argued that Slavutych can be analyzed for its state-like qualities, its stateness, on the basis that it both is assembled by the same processes that states and supranational organizations are assembled and that Slavutych performs its stateness in the same prosaic ways that other state-like polities do. As a result, there is no ontological obstacle for comparing the experiences, development, and actions of Slavutych to any other polity. Slavutych can indeed be a model for post-disaster redevelopment. 


\section{Works Cited}

Anderson, Ben, and Colin McFarlane. "Assemblage and Geography." Area, vol. 43, no. 2, 2011, pp. 124-27.

Atkinson, David. "Geopolitical Imaginations in Modern Italy." Geopolitical Traditions, edited by Klaus Dodds and David Atkinson, Routledge, 2000, pp. 93-117.

Baranovs'ka, Nataliia. Ukraina - Chornobyl' - svit: Chornobyl's'ka problema u mizhnarodnomu vymiri 1986-1996. Nika-Tsentr, 1999.

Barry, Andrew. Material Politics: Disputes along the Pipeline. John Wiley \& Sons, 2013.

Belen'kii, Aleksandr. "Slavutich. Poslednii shedevr imperii." LiveJournal, 6 Feb. 2018. https://macos.livejournal.com/1669209.html. Accessed 28 Feb. 2019.

Brenner, Neil. "Beyond State-Centrism? Space, Territoriality, and Geographical Scale in Globalization Studies." Theory and Society, vol. 28, 1999, pp. 39-78.

---. "The Urban Question as a Scale Question: Reflections on Henri Lefebvre, Urban Theory and the Politics of Scale." International Journal of Urban and Regional Research, vol. 24, no. 2, 2000, pp. 361-78.

Chernobyl Tour. "Tours to Slavutych the Town of Energy." Chernobyl Tour, 2018. https://www.chernobyl-tour.com/slavutich-tour_en.html. Accessed 28 Feb. 2019.

Chernobyl NPP. "Post-Accident Operation and Shutdown." Chernobyl NPP, https://chnpp.gov.ua/en/about/history-of-the-chnpp/chnpp-shutdown. Accessed 15 Sept. 2018.

Cowen, Deborah, and Neil Smith. "After Geopolitics? From the Geopolitical Social to Geoeconomics.” Antipode, vol. 41, no. 1, 2009, pp. 22-48.

Czepczyński, Mariusz. Cultural Landscapes of Post-Socialist Cities: Representation of Power and Needs. Ashgate, 2008.

DeLanda, Manuel. Assemblage Theory. Edinburgh UP, 2016.

DeLanda, Manuel. A New Philosophy of Science: Assemblage Theory. Continuum, 2006.

Deleuze, Gilles, and Felix Guattari. A Thousand Plateaus. Les Éditions de Minuit, 1980 (French); U of Minnesota P, 1987 (English).

Derzhavna sluzhba statystyky Ukrainy. "Perepys naselennia." http://database.ukrcensus.gov.ua/MULT/Database/Census/databasetree_uk.a sp. Accessed 4 Dec. 2017.

Diener, Alexander C., and Joshua Hagen, editors. The City as Power: Urban Space, Place, and National Identity. Rowman \& Littlefield, 2018.

Dittmer, Jason. Diplomatic Material: Affect, Assemblage, and Foreign Policy. Duke UP, 2017.

---. Popular Culture, Geopolitics, and Identity. Rowman \& Littlefield, 2010.

Festival of Film and Urbanism "86." Festival of Film and Urbanism "86," http://www.86.org.ua. Accessed 4 Dec. 2017.

Fomichev, Iurii. Personal interview. 20 Apr. 2016.

Foucault, Michel. Society Must Be Defended. Picador, 2003.

French, R. Antony. Plans, Pragmatism, People: The Legacy of Soviet Planning for Today's Cities. UCL P, 1995.

Graham, Stephen. "Postmortem City." City: Analysis of Urban Trends, Culture, Theory, Policy, Action, vol. 8, no. 2, 2004, pp. 165-96.

Gubkina, Ievgeniia. Slavutych Architectural Guide. DOM Publishers, 2016. 
Hepple, Leslie W. "Géopolitiques de Gauche: Yves Lacoste, Hérodote and French Radical Geopolitics." Geopolitical Traditions, edited by Klaus Dodds and David Atkinson, Routledge, 2000, pp. 268-301.

Hodge, Nathan. "The Town Chernobyl Built." The Wall Street Journal, 25 April 2016. https://www.wsj.com/articles/the-town-chernobyl-built-1461631923.

Accessed 28 Feb. 2019.

Imanaka, Tetsuji, editor. Multi-Side Approach to the Realities of the Chernobyl NPP Accident: Summing-Up of the Consequences of the Accident Twenty Years after. Reactor Research Institute, Kyoto University, 2008.

Jonas, Andrew. "City-Regionalism as a Contingent 'Geopolitics of Capitalism.'” Geopolitics, vol. 18, no. 2, 2013, pp. 284-98.

Kliems, Alfrun, and Marina Dmitrieva, editors. The Post-Socialist City: Continuity and Change in Urban Space and Imagery. Jovis Diskurs, 2010.

Korchak, Ol'ha. Personal interview. 25 Nov. 2015.

Kuus, Merje. Geopolitics and Expertise. John Wiley \& Sons, 2014.

Müller, Martin. "Assemblages and Actor-Networks: Rethinking Socio-Material Power, Politics, and Space." Geography Compass, vol. 9, no. 1, 2015, pp. 27-41.

O'Lear, Shannon. "Climate Science and Slow Violence: A View from Political Geography and STS on Mobilizing Technoscientific Ontologies of Climate Change." Political Geography, vol. 52, 2016, pp. 4-13.

ó Tuathail, Gearóid. Critical Geopolitics: The Politics of Writing Global Space. Routledge, 1996.

---, et al., editors. The Geopolitics Reader. 2nd ed., Routledge, 2006.

Painter, Joe. "Prosaic Geographies of Stateness." Political Geography, vol. 25, 2006, pp. 752-74.

Petryna, Adriana. Life Exposed: Biological Citizenship. Princeton UP, 2002.

Register, Richard. Ecocities: Building Cities in Balance with Nature. Berkeley Hills Books, 2002.

Rokem, Jonathan, and Camillo Boano. Urban Geopolitics: Rethinking Planning in Contested Cities. Routledge, 2018.

Rokem, Jonathan, et al. "Interventions in Urban Geopolitics." Political Geography, vol. 61, 2017, pp. 253-62. http://dx.doi.org/10.1016/j.polgeo.2017.04.004

Ruble, Blair A. "Architecture, Urban Space, and Post-Soviet Russian Identity." Architectures of Russian Identity: 1500 to the Present, edited by James Cracraft and Daniel Rowland, Cornell UP, 2003, pp. 204-14.

Shevchenko, Valentyna. "Provesty demonstratsiiu 1 travnia 1986-ho nakazaly z Moskvy." Istorychna Pravda, $25 \quad$ April 2011. http://www.istpravda.com.ua/articles/2011/04/25/36971/. Accessed 25 Mar. 2015.

Slavutyts'ka mis'ka rada. Plan dii. 1997.

Slavutyts'ka mis'ka rada. Prohrama "Plan dii staloho enerhetychnoho rozvytku mista Slavutych do 2020 roku." 2013.

Slavutyts'ka mis'ka rada. "Investytsiinyi pasport mista Slavutych." Slavutyts'ka mis'ka rada, 2015. http://e-slavutich.gov.ua/about_city/SitePages/Passport.aspx. Accessed 4 Dec. 2017. 
Starr, Megan. "Slavutych, Ukraine: The Soviet City Built for Chernobyl Refugees." MeganStarr, 9 Feb. 2017. https://www.meganstarr.com/slavutych/. Accessed 28 Feb. 2019.

Udovychenko, Volodymyr. Personal interview. 26 May 2016.

---. "Slavutych City-Chornobyl Nuclear Power Plant-Development Perspectives." Chornobyl 30th Anniversary Lecture Series Hosted by Fulbright Ukraine, 13 Apr. 2016, Kyiv, Ukraine. Speech.

“Ukraine Will Close Chernobyl.” The Associated Press, 6 June 2000, p. A7.

Williams, Sean. "The Town Chernobyl Built: How Former Soviet Paradise Slavutych Could Save the Nuclear Industry." Wired, 18 May 2017. https://www.wired.co.uk/article/slavutych-chernobyl-nuclear. Accessed 28 Feb. 2019.

Yekelchyk, Serhy. Ukraine: Birth of a Modern Nation. Oxford UP, 2007.

\section{Archival Material}

Congress of Local and Regional Authorities. "Resolution 215 on Chernobyl, 20 Years On: Local and Regional Authorities Dealing with Disasters." Council of Europe, 31 May 2006.

Holushko, M. to V. Iavorivs'kyi. "Povidomlennia Sluzhby Natsional'noi Bezpeky Ukrainy komisii Verkhovnoi Rady z pytan' Chornobyl's'koi katastrofy pro prychyny porushennia v roboti turboheneratora \#4 ta zahal'nyi riven' avariinoi bezpeky ChAES." 1991. Current archive of the Verkhovna Rada commission on the Chornobyl catastrophe.

Zasedaniia pravitel'stvennoi komissii po likvidatsii posledstvii avarii na Chernobyl'skoi AES. 1986-10-18. "Protokol 10." Slavutych city archives. 